\title{
Comparing Political Participation Levels of Party Members Within the Two Main Parties of Turkey Based on Their Media Usage and Expectations
}

\author{
Orhan Albayrak \\ Department of Political Science and International Relations, Sabahattin Zaim University, Istanbul, Turkey
}

\section{Email address:}

orhan.albayrak@gmail.com

\section{To cite this article:}

Orhan Albayrak. Comparing Political Participation Levels of Party Members Within the Two Main Parties of Turkey Based on Their Media Usage and Expectations. Journal of Political Science and International Relations. Vol. 4, No. 1, 2021, pp. 8-17.

doi: $10.11648 /$ j.jpsir.20210401.12

Received: November 18, 2020; Accepted: January 28, 2021; Published: February 2, 2021

\begin{abstract}
This research aimed to examine the relationships of media usage and party members' expectations with political participation of political party members in İstanbul. The four criteria developed by Robert Dahl about participation are used according to the interest, concern, information, and activity processes. It scrutinized how political party members use social media to acquire political information, how much they are valued and positioned within their parties, and what characteristics they expect their representatives to hold. This study was carried out in three districts of Istanbul. These districts were selected from the three electoral districts in Istanbul and each one of them was assumed to represent one election district. These districts are Avc1lar, Fatih and Kartal. In our study, a mixed research method based on questionnaire and interview was used. A total of 537 people was surveyed, and in-depth interviews were conducted with 21 people working at different levels in the parties in these three districts. The results indicated three main findings. Firstly, both party members preferred to follow up with what happens in political agenda using social media rather than traditional media outlets. Secondly, both party members stated that they would like to be a local assembly member or a national assembly member but have no interest in becoming a local mayor or a chairman of party's local region/city. Moreover, both party members believed that they are not in the roles/positions they deserved and do not receive the value and importance they deserved within their parties. Finally, both party members expected their party representatives to be honest and honorable, rather than charismatic, rich, brave, and decisive, or hardworking. Overall, these findings suggest that although both parties are located on different sides of politics, there is no significant difference between Ak Party (JDP, Justice and Development Party) and CHP (RPP, Republican People Party) on these issues.
\end{abstract}

Keywords: Political Participation, Media Usage, Social Media, Party Membership, Party

\section{Introduction}

In this article, political participation level of party members served in different levels of political positions who have senior positions in the regional and township organization, and who actively involved in some of the representative positions, and who have previously worked in those positions within the two main parties (JDP, Justice and Development Party and RPP, Republican People Party) one from the center right and the other from the center left in Turkey are examined in in terms of "social media" and "member's expectations from their parties". How both party members use social media, how they acquire political information, whether their parties owe them importance and relevance, and whether they take office in their parties have also been examined.

\subsection{Political Parties}

Political parties, which are indispensable elements of democracy, and which are organizations that have a certain program, act to take over the management or share with others and have a permanent organization. In other words, a political party is a political organization composed of individuals. There are two common features in all political 
parties: One of them is that the parties come to power and want to rule the country or become a partner in power; the other is that they organize a large number of people under a certain organizational structure for this purpose.

Political parties are the main political actors of democracies. It is thought that it is necessary to understand the functioning of the system in countries not only by looking at the laws and institutions, but also by looking at the parties and the internal functioning of the parties, and in this respect, it should be emphasized that the political participation of party members is important. Because one of the important indicators of democracies is the participation of the segments of the society in the political decision-making process. Political parties mobilize individual and group social segments and integrate them with politics. The tightest bond that can be established between a party and voters can be realized through the members of the party [27].

It should not be forgotten that political parties are a hierarchical organization, they realize this organization with a widespread and wide organization, and they have a party program that they will implement when they come to power. Integration of interests among the functions of the parties to the current political system, teaching voting, which is an important way of political participation, etc. Providing political socialization, including the capital of political parties by directing the voters to the ballot box, ensuring the integration of citizens with the political system, government and the state to work, if the party is in opposition, the opposition and the control of the government, finding and training leadership cadres. Çetin [10] considers political negotiation among the functions of political parties in addition to the above.

\subsection{Political Party Membership}

Parties realize their goals and functions through their members. At this point, party members are expected to be effective by fulfilling the expectations of the party. Party members are expected to work to increase the awareness of their parties and to encourage non-party members to support and vote for the party in elections. It is thought that the communication with the society will be stronger if the excess of party members and their participation in party activities is high.

\subsection{Political Participation}

Political participation includes two important actions such as choosing the administrators and influencing them. Social science researchers have attracted the attention of election, election and influencing the decisions of the ruled, which is important for political participation, which has a significant place in the understanding of democratic governance.

\subsection{Political Participation Levels}

Individuals who participate in politics do not participate in the same level of political participation. Because many factors such as how individuals go through the process of political socialization, the political culture of the society they live in, the socio-economic structure of the society differ in their level of political participation. In this framework, it is seen that political scientists examine the level of political participation using different criteria. Çaha [6] states that political participation occurs at three levels in democracies: participation at the personal level, at the group level, and through political parties.

In the study, Dahl's approach was taken as a basis in terms of the level of political participation. According to this approach, Dahl [13] grouped the levels of political participation as follows: level of interest, level of concern, level of information and activity level. At the level of interest, what is happening around the person attracts attention. He begins to care about whether the decision he will make about the event he is interested in is important or not. At the level of knowledge, people check whether they have enough information about this decision they care about. He finally decides what action he will take on this decision. Dahl [13] demonstrated how society behaved at the four levels above in the presidential elections of 1957 in the USA. Those who showed little interest in the presidential elections and those who did not care did not need to obtain much information and did not vote in the elections. On the other hand, those who showed great interest and care first got the information and mostly cast their votes.

According to this approach, the person starts the process of being interested in whatever is interested in creating a political participation. Behind this, the process of caring for the subject of interest begins for the continuation of political participation. Later, in the informing process, the person starts to collect information and eventually, the action process regarding that issue is activated. In the first stage of participation, the person is limited to curiosity, inclination and desire for political events. In the next stage, he cares about political events. In the next stage, the informing process comes into play. The person is now watching political events. He is now closely interested in politics, watches television programs about politics, reads political articles in newspaper columns, and follows political accounts on social media. In the stage of action, which is the last level of political participation, the person is now in political events It is thought that politics has started to take an important place in that person's life.

\subsection{Number of AK Party and CHP Party Members}

As of February 2020;10,195,904 people with respect to the number of members of the Justice and Development Party who took the first place; $1,257,753$ people with the Republican People's Party second, 479199 people with the Nationalist Movement Party is in third place [28].

In the districts subject to the study, the number of CHP party members in Avcilar, Fatih and Kartal is 11.907, 4.124 and 15.988, respectively, according to the information received from the CHP's Avc1lar, Fatih and Kartal District Branch as of July 2020. Likewise, according to the information obtained from the Ak Party Istanbul Branch, the 
number of members is 65,144, 68,606 and 55,962 respectively in Avc1lar, Fatih and Kartal as of July 2020. The number of party members of AK Party and CHP throughout Istanbul is $2,319,483$ and 271,787 .

Turkey has defined how members will be provided with legal political parties. Unless there are cases against the law, parties have determined the conditions for membership in their statutes [22]. In the middle of 2012, party member registrations were made available to citizens on the internet [29].

\subsection{AK Party (JDP, Justice and Development Party)}

AK Party was established on 14 August 2001. Defining itself as Conservative-Democrat, the Ak Party is located to the right of the political lane. However, it follows the liberal line as an economic understanding. An important part of its founders and prominent figures comes from the line of "National Vision", which is thought to be positioned on a line that takes Islam as a reference. The staff of the former Virtue Party in the line of National Vision passed to the Saadet Party after the dissolution of this party. Those who did not join the Fazilet Party were in the AK Party. During its foundation years, an inclusive approach was adopted and many people from different segments of the society and with different political views took part in the party. Being shown as an extension of a party is rejected by the AK Party. AK Party Chairman Recep Tayyip Erdogan stated that the party's place in the political spectrum is conservative democracy [26].

\subsection{CHP (RPP, Republican People Party)}

CHP was founded by Atatürk on September 9, 1923. Its first name is "People's Party", then it changed its name to "Republican People's Party" in 1924 [12]. The principles of "Statism" and "Revolutionism" were added to the principles of "Republicanism", "Populism", "Nationalism" and "Secularism" in 1927 and the number of principles reached six [11]. CHP ruled the country alone from its establishment until 1950. "He pioneered the institutionalization of the opposition in a democratic regime with the opposition task he assumed in the 1950s" [11]. CHP positioned itself "on the left of the middle" in the 1960s and defined its ideology with the concept of "democratic left" in the 1970s. In this process, CHP claimed that the party, with its own words, transformed from "state party" to "people's party", from "order party" to "change party" [11]. The slogan of the period is: "Tiller of Soil, Who Uses Water" and "This Order Must Change". During this period, the CHP became a member of the Socialist International and the European Socialists Union.

\subsection{Tendency of Party Members to Use Social Media}

Internet, which has become an integral part of our daily life, is thought to be an important media for reaching any information we want and communicating with our environment. On the other hand, Çalışkan [8] states that "a new 'public space' is developing with the Internet". According to Gürbüz [18], "Public space is defined as the state has no coercive apparatus, discourses are free and communicative is diverse". The Internet is an environment where people create social networks by expressing their feelings and thoughts in different ways (voice, picture, video), interact with each other through these networks, follow each other's shares and share. Çaha et al. [7] say the following on this subject: "It would not be wrong to say that the internet environment, hence social media, took the place of squares. Social media has taken the place of expressing feelings and thoughts in the squares". Using social media, all kinds of feelings and thoughts are expressed in different networks [9]. "One of the most widely used mass media today is the internet and social networks or social media created in this way. The dissemination, presentation and use of information via social media is much different than other mass media" [14]. In a study called "The role of the internet in the political participation of party members" in Sussex in England, it is emphasized that the internet has a great role in political participation and shaping party policies [23]. With the emergence of the world wide web, one of the most important inventions of the modern world, information has reached almost every point. Beginning at the end of the 20th century, but as a result of the developments in the 21 st century, people who live in any part of the world and do not even know each other have the opportunity to communicate easily and instantly through internet technologies. Such a sudden development of technology has transformed the world rapidly, beyond being a 'global village', into a space where people watch and follow each other on electronic screens, 'virtual worlds'.

Unlike traditional media, new media are both easier and faster accessible and can be consumed more easily. Digital technology opens the way to be easy, fast and consumable [30]. The widespread use of the Internet everywhere, mobile phones becoming more powerful both in terms of hardware and software, unlike other mass communication tools, digital technology, and software-controlled devices (Internet of Things) make new media more important. Lister et al. [24] gathered the characteristics of new media under the titles of digitality, interactivity, hyper-textuality, distributed and virtuality. What is meant by digitality is that data in traditional media is physical, whereas in internet media, data is expressed in numbers, ie zeros and ones. Since processing of digital data is easier than analog data processing, accessing data in digital systems is more accurate than analog because it is both fast and digital [24]. With the presence of interactivity, in new media tools, users can change the content and thus use the media according to their own wishes. In this case, new media users cease to be passive individuals and become individuals who actively participate in the interaction phase. Because interaction allows users to change content. Hyper-textuality, with its flexible structure offers endless possibilities to users. Another important concept in new media is hyper-media. The use of very distinct media such as text, sound, image and video in new media together and interactively is hyper-media [25]. Production and presentation in the classical media environment have certain 
standards and a structure that spreads from the center to the periphery. In the new media, the situation is completely different. Because there is no centrality in this new communication environment. The messages are not synchronized. Messages are also not in a single format. People can be producers or customers by means of distributed feature. Lister et al. [24] explain this situation as "This is why the production and distribution of new media has become personalized and reduced to daily life, not centralized". Virtuality is the feature that gives people the "feeling of being there". In this sense, Binark [5] states that "New media offers two types of communication, the first being between machine / artificial intelligence and human (user) and the second being communication with other people (users)". Another important concept, "Virtual Reality", enables people to make all kinds of simulations in interactive environments. As a result, Heim [19] interprets this situation as "The idea that new communication technologies offer an unrestricted freedom of expression by eliminating the formal and hierarchical system of the real world increases the user interest in the virtual reality of social media". Social networks such as Facebook, Twitter, and Instagram have an important role in increasing the power of large political parties with a large voter base. When the rate and frequency of media coverage is compared with the cost of owning a website, the economic benefits of the internet can be mentioned first. Social media helps to eliminate the imbalances in terms of communication that may occur due to the size of the party and the parties' being in power in terms of democratic process and brings all parties to an equal level in the virtual environment. Small political parties that could not be heard in the media also turned to social media that was cheaper in reaching voters and did not contain any pressure element.

With the questions asked in the survey below, the effects of social media on political participation and the potential of the internet and social media to affect political participation are examined through party members.

At this stage, based on the idea that party members are closely related to their own lives, it has been examined how they care about political events and their party.

The importance of social media in terms of political participation of party members is increasing day by day. Party members meet their need for information about politics by using social media. "Social Media is used by political parties and politicians to direct people to political participation" included in a study. In addition to this, "social networks are used as a propaganda tool especially during election periods" gives concrete information about the use of this social media.

In this section, party members of the AK Party and CHP perceive their own parties; are the relevant members fully aware, what is clearly happening; how the discipline of the party is implemented; the leadership skills and the characteristics needed by that office are considered when appointing to party ranks; generally, studies will be emphasized on how the party's works style.
Which media do party members try to influence party management? To what extent do party members follow their own parties on social media? Where do party members learn about politics? The answers to the questions were sought and

the results obtained were evaluated in this section. In this framework, the political participation opportunities of party members through social media, friends, family and television were measured and how they learned about politics was examined.

Table 1. Do you use the internet? If so, how often do you use it?

\begin{tabular}{lll}
\hline & Ak Party (\%) & CHP (\%) \\
\hline Less than an hour a day & 20,2 & 16,7 \\
1-3 hours a day & 34,4 & 36,4 \\
4-6 hours a day & 26,8 & 27,6 \\
More than 7 hours a day & 16,6 & 17,5 \\
I never use & 2 & 1,8 \\
Total & 100 & 100 \\
\hline
\end{tabular}

As seen in Table 1 on "Internet usage", when the attitudes of both party members are examined, there is no statistically significant difference according to the t-test results $(\mathrm{p}=.454)$. The rate of those who do not use the internet is low among the members of both parties. The internet usage rate of more than 7 hours a day is approximately the same for both party members. These results are also in accordance with the research on society. In the study titled "The Effects of Social Media on Creating Public Opinion and Political Participation: A Theoretical and Empirical Analysis", it was determined that people mostly use the internet for 1-3 hours, followed by 4-6 hours of use [16]. As a result, internet usage is important level both among AK Party party members and CHP party members.

Table 2. For what purpose do you use the internet most?

\begin{tabular}{lll}
\hline & Ak Party (\%) & CHP (\%) \\
\hline To watch what is happening in the world & 40 & 49,8 \\
To investigate some topics & 26,1 & 24,4 \\
For chat with friends & 15,6 & 9,8 \\
For entertainment / music & 5,8 & 6,2 \\
Other & 12,5 & 9,8 \\
Total & 100 & 100 \\
\hline
\end{tabular}

In the answers given to the question about "For what purpose both party members use the internet", the option "To monitor what is happening in the world" seems to be far ahead of the other options. Members of both parties use the internet for chat and entertainment lower than those who use the internet to watch what is happening in the world. The use of AK Party party members for "chatting with friends" is slightly less than twice that of CHP party members for this purpose. Again, the members of both parties use the internet "to search some issues" in the second place. In Göksu's study "Effects of Social Media on Creating Public Opinion and Political Participation: A Theoretical and Empirical Analysis", the results obtained from the study for the "purposes of internet use" coincide with the results we obtained for party members. According to the findings obtained there, $72.12 \%$ of the participants use the internet "to follow the agenda" 
[16].

Table 3. Do you use the following social media tools?

\begin{tabular}{lllllll}
\hline & \multicolumn{2}{l}{ Ak Party (\%) } & \multicolumn{2}{c}{ CHP (\%) } & \\
\hline & I never use & Sometimes I use & I use a lot & I never use & Sometimes I use & I use a lot \\
\hline YouTube & 12,8 & 34,1 & 53,1 & 15,5 & 38,7 & 45,9 \\
WhatsApp & 4,4 & 15,4 & 80,2 & 3,3 & 18,1 & 78,6 \\
Twitter & 15,5 & 29,5 & 55 & 36,8 & 28,7 & 34,5 \\
Telegram & 79 & 14,2 & 6,8 & 88,8 & 6 & 5,2 \\
Messenger & 29,7 & 37,8 & 32,5 & 16,2 & 41,3 & 42,5 \\
Instagram & 12,4 & 26,6 & 60,9 & 19,6 & 21,7 & 58,7 \\
Facebook & 14 & 33,9 & 52,1 & 3,3 & 29,8 & 67 \\
Bip & 71,9 & 19,2 & 8,9 & 89 & 6,6 & 4,4 \\
\hline
\end{tabular}

Social media is one of the most used media on the internet. Social media tools such as YouTube, WhatsApp, Twitter, Facebook, Instagram are used for purposes such as communication, discussion, and announcement. Güngör [17] emphasizes the use of social media among party members in his work called "@Status of politics: Political Participation in the Digital Age":

Electronic methods are reaching an expanding area of use in the internal work of political parties. The flow of information about policies and decisions between the center and the provinces has been accelerated through web-based platforms that provide direct communication with members or local organization managers. Polls where delegates, members and even volunteers can participate with a password, and opinion polling is carried out in the candidate selection process during the election period.

As can be seen in Table 3, where the use of social media tools and to what extent the members of both parties use social media tools, "WhatsApp" is the most used social media tools among both party members. Among the reasons for this use, free communication is thought to be an important reason. With this type of communication, party members can use sound (speech of the president, music, etc.), text (such as correspondence between party members and organizations), pictures (such as event images, graphic design images, printed brochures) and videos (prepared by the party for different purposes, propaganda). purposeful videos, speeches, group speeches of the party leader) without limitation. Another important reason is the different groups established among party members. For example, district presidency group, neighborhood management group or groups established for different purposes. In this way, announcements can be made very quickly. In addition, as a feature of WhatsApp, it can be checked whether the sent message is read or not. WhatsApp can communicate with other electronic media without any problems. WhatsApp is very advanced in receiving and sending all kinds of information from other media. These and similar features put WhatsApp in an advantageous position compared to other social media tools. This is followed by Instagram, YouTube and Twitter.

Use of "Beep" and "Telegram" is low among Ak Party members. Among CHP party members, WhatsApp is the most used social media tool. Facebook is following this. Instagram and Messenger usage is also high among CHP party members. Twitter comes after all this. Another point that should be emphasized is that Twitter usage is low among CHP party members. In general, CHP party members use the social media as a whole, compared to the members of the Ak Party. Because CHP party members use over 50 percent of all social media tools except Bip and Telegram. However, members of Ak Party focused on four social media tools (Twitter, YouTube, WhatsApp, Telegram). The use of "Bip", a local social media tool, is almost nonexistent among party members of both Ak Party and CHP. In the above-mentioned study, people were asked about the "social media platforms they are members of", and as it is understood from the answers received, Facebook emerged as the most popular media network among the participants [16]. Likewise, with the widespread use of WhatsApp and smartphones, especially smartphones with advanced camera features, Instagram, a mobile application where users share photos and interact.

When analyzed statistically, there is a significant difference between Ak Party and CHP members in terms of Facebook usage according to the t-test results $(p=.001)$. Likewise, there is a significant difference between Ak Party and CHP members in terms of Twitter usage $(p=.001)$. In terms of YouTube usage, there is a difference between the members of both parties, although the usage is close to each other $(\mathrm{p}=.047)$. Although the rates in Table 3 are different, there is no significant difference between the two-party members in terms of WhatsApp usage $(p=.094)$. It is observed that there is no significant difference between the members of Ak Party and CHP in terms of Messenger usage $(p=.006)$. In terms of Instagram usage, there is no significant difference between AK Party and CHP members $(p=.150)$. There is a significant difference between the AK Party and CHP members in terms of the use of beeps $(p=.001)$. The use of beeps is twice that of the CHP among Ak Party members. In terms of the use of Telegram, there is no significant difference between AK Party and CHP members $(\mathrm{p}=.503)$.

Table 4. Where do you learn about politics?

\begin{tabular}{lll}
\hline & Ak Party (\%) & CHP (\%) \\
\hline From social media & 41,4 & 49,6 \\
From television & 30,5 & 25,4 \\
From the circle of friends & 6,2 & 8,9 \\
From my family & 6,2 & 1,3 \\
From the radio & 4,5 & 1,3 \\
Other & 11,3 & 13,4 \\
Total & 100 & 100 \\
\hline
\end{tabular}


"Where do you learn about politics?" It was tried to get information about the process of informing the members of both parties on politics.

Looking at Table 4, nearly 50 percent of both party members get information from "social media". Television comes second. Other information retrieval options are below 10 percent each. It was concluded that the "circle of friends" was not very influential in the process of informing about politics, and the "family" had a very limited influence on this issue.

Developments in technology, development of mobile technologies, widespread use of the internet are thought to open up new communication opportunities for political parties. One of them is the web page. The statements of the chairman and other party organization members, news about party activities, and announcements about the organization stand out on the parties' websites. These publications are oneway notifications that are closed to interaction. In addition, information about social media accounts is also provided on the websites of the parties. Ak Party and CHP publish the download links of their mobile applications where party news can be followed on their website. All these play a role in determining the ways party members obtain information about the parties they are members of. It is thought that these applications are the reason for the high rate of social media in surveys.

Table 5. Do you follow your party's social media accounts?

\begin{tabular}{lll}
\hline & Ak Party (\%) & CHP (\%) \\
\hline I never follow & 5,7 & 8,8 \\
I rarely follow & 11,8 & 10,6 \\
I have no idea about it & 1,4 & 0,9 \\
I follow as needed & 23 & 24,3 \\
I follow very carefully & 57,8 & 55,3 \\
Other & 0,3 & \\
\hline
\end{tabular}

"Do you follow your party's social media accounts?" Considering the answers to the question, the first noticeable in Table 5 is that both party members "very carefully follow their parties' social media accounts". With the option of "I follow as needed", this rate reaches approximately 80 percent.

When analyzed from a statistical point of view, according to the t-test, there is no significant difference in following the social media accounts of the party members of both parties ( $p$ $=.405$ ). Asked in the study titled "The Effects of Social Media on Public Opinion Formation and Political Participation: A Theoretical and Empirical Analysis", "Where Do You Follow the Events Occupying the Public Agenda?" As can be seen in the answers given to the question asked "Social Media and Internet" usage is at a high rate of $88.63 \%$ [16]. These results are consistent with the results we obtained in the study for party members. Because party members of both parties, with a ratio of over $55 \%$, carefully follow the social media accounts of their parties.

When the political participation opportunities of the party members were evaluated, it was concluded that social media was predominantly preferred and followed.
Table 6. Through whom do you receive information about the party you are a member of?

\begin{tabular}{lll}
\hline & Ak Party (\%) & CHP (\%) \\
\hline By following my party's social media & 42 & 33,5 \\
Newspaper, radio, TV & 27,8 & 18,3 \\
By visiting my party's website & 7,8 & 13,8 \\
With emails from my party & 5,4 & 12,9 \\
Print publication of my party & 9,5 & 5,8 \\
Through friends & 2,7 & 8 \\
Other & 4,7 & 7,6 \\
Total & 100 & 100 \\
\hline
\end{tabular}

"Through whom do you receive information about the party you are a member of?" When we look at the data in Table 6 regarding the question, it is seen that both party members receive information about the party of which they are members by following the social media account of the party. However, this rate is 10 percent higher in the Ak Parti than the CHP. In the second place, newspapers, radio and TV come in both parties. However, in terms of getting information about the party from newspapers, radio and television, the Ak Parti is 1.5 times higher than CHP. When the members of both parties are compared in terms of visiting the websites of the parties and getting information, CHP party members visit the websites approximately twice as much as the members of the Ak Party. In terms of obtaining information about the party via e-mail (mail), the rate of party members with CHP is approximately twice as high as AK Party members. It is observed from this table that the option to get information through the "printed publication of the party" and "Friends" is ineffective in getting information about the party.

Bayraktutan et al [3] conducted by the "Investigation of Political Communication Applications of Social Media: Turkey in the 2011 General Elections Facebook and Twitter Political parties and leaders by Using" named in the supported research projects by TUBITAK, web 2.0 democratic participation starting from the assumption that contribute to the development of civic culture originated, Twitter and Facebook in 2011 by leaders of political parties and general elections in Turkey was examined in practical use. According to the results, it was determined that the political representatives reflected their party policies at the discourse level through these tools. Based on this study, it is thought that social media is a widely used environment for party members.

All these studies confirm the results we obtained in our surveys and show that the role of social media is important in terms of political participation of party members.

As a result, it has been observed that both AK Party members and CHP party members follow political issues mostly on social media and follow their parties' social media accounts "very carefully". It is thought that this situation can be explained by the widespread use of the internet, the interaction of social media compared to traditional media, and the transition of the party member from passive to active. 
Table 7. Do you think the party you are a member of gives you the necessary importance "as a party member"?

\begin{tabular}{lll}
\hline & Ak Party (\%) & CHP (\%) \\
\hline No, it doesn't give & 17,7 & 16,7 \\
Usually does not & 20,1 & 22,5 \\
Whether it gives or not is understood & 14,6 & 14 \\
over time & 23,5 & 22,1 \\
Yes, it gives sometimes & 24,1 & 24,8 \\
Yes, it always gives & 100 & 100 \\
Total & & \\
\hline
\end{tabular}

Asked to the respondents, "Do you think the party you are a member of gives you the necessary importance" as a party member "? When the question is asked, approximately 40 percent of the members of both parties' state that when the "no does not give" and "generally not" options are evaluated together, the necessary importance is not given. However, again, more than 45 percent of party members in both parties' state that the necessary importance is given. According to the results of the t-test of the party members of the two parties, there is no significant difference between the two groups. Both party members have the same attitude towards this issue $(\mathrm{p}=.965)$.

In an interview held as a party member, Avcilar CHP Former District Chairman E. B. [15] put forward his thoughts as follows:

Parties do not give due importance to party members. They do not provide the necessary environment for party members to rise in politics. Our party does not provide it, and the Ak Party is even more limited. Everything happens from the top, the members' participation in this process is limited.

In these statements, E. B. [15] emphasizes that the CHP does not have an established policy for promoting party members to higher levels. From these expressions, it was underlined that it is difficult to be employed at the higher levels of the party in practice. In addition, it is understood that the personal qualities of the people (education, experience, knowledge, etc.) do not play much of a role in advancing to higher levels. In-party democracy is also emphasized partially, and it is emphasized that the top management of the party is very effective in the decision process. An interesting point here is that as a CHP party member, he thinks this situation is worse in the Ak Party.

The statements below reflect the views of Avc1lar AK Party Istanbul Greater Municipality Assembly Member H.I. [20]:

The importance for party members depends on what you put and buy the combined containers account. If they assign and embrace them, they are given importance by the party, otherwise they remain a simple party member.

H.I. [20] attributes the importance to party members directly to the extent to which party members embrace their ability to perform their duties and what they do in that position. In addition to the above, he thinks that they will be cared for as long as they adapt to the team they are in and show a strong will to obey their superiors. He emphasizes that if they don't, they don't have a chance to rise anyway.
Another Ak Party Former District Chairman A.K.P. [2] expresses his thoughts on this issue as follows:

Respected and right people are looking at very cold to the politics. In other words, they do not want to get involved in politics, because there is a very serious contact with the people, especially in the politics of the Ak Party, and you have to devote a lot of time to this work. If you cannot spare more time, there is no chance of success. Therefore, 90\% of the people with competence and competence have their jobs and strengths and their families are a serious obstacle to this. Until now, I have not come to any office as a candidate, I do not find it wrong to aspire, it may be a desire to come to the office, it is very true, I see it as wanting to serve. I never had the thought that I should be in a better place.

With an interesting statement, the district president emphasizes that $" 90 \%$ of the competent and competent people have their jobs and power and their families do not allow them to engage in politics" and emphasizes that such people do not engage in politics. In other words, he says that politics can be done by people who have no work-power and therefore can devote a lot of time to politics. This is important in that it reveals an interesting approach for the profile of the politicians in the AK Party. Another point that is emphasized is that politics should not be done "for the position of authority" and it should be done for "service". In other words, he expresses his thoughts as "you as a party member should only be in the party to serve, you should not do politics for position and office." It also underlines the need to have the mentality of "duty is not requested, task is given". With this approach, the message given to party members is that "party members exist thanks to the party". Another message is that they have to wait until they are "assigned". The president expresses this when he says, "I never had the idea of being somewhere." But in practice "Who goes up?" What happens in practice when asked the question; It is seen that an approach that first shows loyalty, then those who have merit-competence prevails.

AK Party Municipal Council Member B.Ç. [4] answered briefly and clearly "partially" about the importance given to party members. This statement shows that the Ak Party does not always appreciate party members, and that the value it gives changes according to the situation and time.

Table 8. Do you think party members can get to the places they deserve in your party?

\begin{tabular}{lll}
\hline & Ak Party (\%) & CHP (\%) \\
\hline They usually get & 14,4 & 8,1 \\
Sometimes they can get & 17,2 & 18,5 \\
Depends on coincidences & 8,2 & 7,7 \\
They rarely get & 30,6 & 30,2 \\
No, they can't get & 29,6 & 35,6 \\
Total & 100 & 100 \\
\hline
\end{tabular}

"Can party members get the place they deserve in your party?" When the answers to the question are examined; In addition to "No, they cannot come", the total of "Rarely coming" is more than 60 percent. It is thought that it is not 
easy for party members to reach their deserved place in both parties. The rate of members who say "they usually come" is 50 percent less in CHP than Ak Party. "Rarely", on the other hand, seem close to the same in both parties.

When the question is examined in terms of the evaluation of the two-party members, it is seen that there is no difference in terms of the AK Party and CHP members in their parties in terms of getting the place they deserve. This is difficult in both parties. According to the results of the t-test performed on the two groups, there is no difference between the members of the Ak Party and the CHP in terms of achieving the place they deserve $(p=, 064)$. As can be seen in the table, the rates of AK Party and CHP members reaching the place they deserve are close to each other.

Former Deputy Minister of Health and Head of AK Party Fatih Founder District A.B.Ö. [1] expresses his thoughts on this issue as follows:

Generally speaking, I think I am where I deserve. Of course, it is a difficult question when asked personally. But I think that now, after 18 years of your education, consider a friend who has served as District President, Deputy, Deputy Head of the Headquarters Organization and has knowledge and skills. I think I am where I deserve. However, many of our qualified friends were ignored. We had a lot of qualified friends, someone like me, all of them were pacified by the party under the name of 'metal fatigue' and played with the future of the party.

A.B.Ö. [1] states that the AK Party attaches importance to the party members, since he has taken many positions in the interview. However, it draws attention to a subject called "metal fatigue". Metal fatigue: It is the structural damage of a part that is exposed to a load due to this load over time, it becomes dysfunctional. Here at the AK Party, before the congresses, the Party Chairperson frequently used this expression to signal that a "renewal" process would begin in the Ak Party organizations. The term "metal weary" was frequently used in organizations, both for age and for former party members. In the above interview, it was stated that many party members, who were tired of metal, were left out, so that the party members who should be cared for were ignored and that they played with the future of the Ak Party by being pushed out of the party at once. Young and inexperienced people who came to work as part of a "team" in a short time, with an attitude of "loyalty" rather than merit and competence, in the foreground. A.B.Ö. [1] emphasizes that this is hurting the party.

CHP Former District Chairman E.B. [15] draws attention to the following issues in this regard:

Parties do not give due importance to party members. I think the parties do not provide the necessary environment for the promotion of party members in politics. It doesn't provide enough for our party. For the AK Party, it is even more limited. Everything happens from the top, the members' participation in this process is also limited. It is not clear how we will take office in the Republican People's Party, but it is clear how.

E.B. [15], an experienced district president, emphasizes that the CHP does not have a problem to increase the quality of party members, at least it is not in such an effort, everything is done from the top, party members participate politically and cannot influence the decisions of the senior management. When he says that it is not clear how you will come to office in the CHP, he underlines that there is actually no defined path, someone who is "in good relations with the top management" can come to any position, but how you will be dismissed is certain, as required by the statute, you can be dismissed immediately before your duty expires.

Generally, each generation sees the previous generation as more conservative and reactionary, while the next generation sees them as irresponsible and disrespectful. While the new generations are more open to innovation and tend to adopt developments compared to the old generations, the older generations have difficulty in adapting to the innovations despite their strict adherence to their traditions and backgrounds.

\section{Results for Expectations}

From all these expressions, it is understood that in the past, the will of the lowest units of the party was effective in determining the people who will take part in the party ranks, and now the people at the higher levels of the party are more effective in bringing people to the higher levels.

Almost all of the party members interviewed (except for one Deputy Minister - who also emphasized that party members were not getting where they deserved) expressed their opinion that party members could not easily get where they deserved.

It is thought that there are six reasons for Party Members not to get where they deserve:

First one; Today, people or party members are considered to be more individualistic and less idealistic than before. It is believed that their idealism negatively affects the party members' getting where they deserve.

Latter; It is observed that responsible, honest, and successful people do not want to take part in parties, they stay away from parties, in other words, such people are kept away from parties because they are thought to be in favor of the "righteous things" in terms of "obedience" and "loyalty."

Thirdly, it is observed that the top management of the party is effective in determining candidates, and fairways such as "pre-elections" where more democratic and political participation and participatory understanding are at the forefront are not adopted.

Fourth; As it is tried to be explained with the words "level and respected politics is a thing of the past", it is thought that a more "populist" and "pragmatic" understanding of politics is dominant today. As stated in the interviews above, it is thought that pragmatic ways rather than principled approaches are chosen to reach the result. For example, the fact that people who have spent their years in a district are put aside at once and assigning a "good image" and "team" to many people in parliamentary membership and at other levels indicates that the feeling of winning an election rather than 
principal approaches has affected the party administration.

Fifth; Another application of such approaches is, for example, instead of running political participation channels in both parties in a district where it is certain that the election will be won, a relative of the senior party executives or a strong member of the group that has formed a "team" within the party is either nominated or placed as a member of the parliament. This also makes it easier to follow the pulse of that district "from above".

Sixth; Due to the reasons arising from the conflict between generations, the "old ones" within the party find it difficult to pave the way for the new generation.

Another important conclusion reached in the study is that party members expect the elected in both parties to be honest and honest, and then to be brave and determined.

Both party members are highly devoted and loyal to their parties. However, it was concluded that their parties did not give enough importance to themselves and that most party members did not get the places they deserved in both parties.

Another important finding that we have obtained is that the majority of the members of both parties do not apply for candidacy in local or general elections.

\section{Results and Conclusions for Social Media}

The first point we will express within the scope of the research findings is that the party members of both parties have different opinions on many issues and have different ideological and identity preferences but exhibit the same attitude and behavior on many issues. There is an ideological split between party members, but it is a finding that they have similar attitudes towards similar events.

Social media paved the way for political participation and increased the political participation of party members. As a new form of political participation, social media gains importance day by day. Compared to traditional media, which is a one-way and only sender, new media consisting of internet, social media, mobile phones, digital software and technologies and rich content both sender and receiver have started to enter our lives more. This paves the way for the individual's political participation. Social media plays the most effective role in political participation compared to all channels. In this study, it was observed that the members use social media a lot and follow the social media accounts of their parties very carefully.

Both party members are highly devoted and loyal to their parties. However, it was concluded that their parties did not give enough importance to themselves and that most party members did not get the places they deserved in both parties.

Another important finding that we have obtained is that the majority of the members of both parties do not apply for candidacy in local or general elections.

Since the members of the society know that they can influence the decisions of decision makers through political parties, it is thought that they are aware of the need to take part in political parties for this effect to occur. Although membership of a political party can be achieved easily in the AK Party and the CHP, which are the two most influential parties at the center of Turkish politics, theoretically, it does not seem as easy to take part in management positions. The political participation and attitudes of the party members were measured and confirmed by the polls and interviews conducted with the management positions and members of both parties.

It is thought that loyalty is often prioritized in parties, party top management prefers people who are loyal to them, and thus, the administration of the party becomes easier thanks to these people who can easily control them. The presence of these persons reveals the presence of those who have different internal party duty expectations in the party, both at different levels of the organization and in the form of expectations in the bureaucracy. This attitude resembles the existence of a group called the "elite class" formed by Pareto, Mills and Mosca while evaluating the society [31]. It is believed that this class ultimately forms a power within the party.

\section{References}

[1] A. B. Ö. (2019). Ak Party Fatih Former District Chairman, Former Deputy, Deputy Minister. Interview: Orhan Albayrak, Istanbul, 8 August 2020.

[2] A. K. P. (2019). Ak Party Üsküdar District Chairman. Interview. Orhan Albayrak, Istanbul, 17 July 2020.

[3] Bayraktutan, G., Binark, M., Çomu, T., Doğu, B., İslamoğlu, G., \& Aydemir, A. T. (2012). Sosyal Medyada 2011 Genel Seçimleri: Nicel ve Nitel Arayüzey İncelemesi. Selçuk Üniversitesi İletişim Fakültesi Akademi Dergisi, 7 (3): 5-29.

[4] B. Ç. (2019). Ak Parti Avcılar Municipal Council Member. Interview. Orhan Albayrak, Istanbul, 17 March 2020.

[5] Binark, M. (2009). Yeni Medya Dolayımlı İletişim Ortamında Olanakların ve Olamayanları Farkında Olmak. Evrensel Kültür Dergisi, 216, 60-63.

[6] Çaha, Ö. (2015). Seçmen Davranışı ve Si yasal Parti ler. In Orion Yayınevi-Ankara (2. Bask1).

[7] Çaha, Ö., Çaha, H., \& Okur, S. (2019). Kadın ve Siyaset (1. Bask1). Turkuvaz Haberleşme ve Yayıncılık A. Ş., İstanbul.

[8] Çalışkan, O. (2014). Kamusal Alan Bağlamında Ağ Toplumu ve Yeni Kamusal Alan Arayışı. Maltepe Üniversitesi · İletişim Fakültesi Dergisi, 1 (1), 57-60.

[9] Castells, M. (2013). Enformasyon Çağı: Ekonomi, Toplum ve Kültür-Kimliğin Gücü (A. Telli (ed.); Üçüncü Bas). İstanbul Bilgi Üniversitesi Yayınları 132.

[10] Çetin, H. (2016). Siyaset Bilimi (H. Çetin (ed.); 6. Basım). Orion Kitabevi, Ankara.

[11] CHP Tarihi. (2015). Chp Tarihi ve İdeolojisi. Erişim Tarihi: 7.7.2020. https://www.chp.org.tr/haberler/chp-tarihi

[12] CHP Tüzük. (2018). Cumhuri yet Halk Parti si Tüzük 2018.

Http://Content.Chp.Org.Tr/File/Chp_tuzuk_10_03_2018.Pdf. 
[13] Dahl, R. A. (1963). Modern Political Analysis (R. A. Dahl (ed.); First Edit). Englewood Cliffs, Prentice Hall, Inc., NewJersey.

[14] Demir, S. E. (2016). İnternetin Politik Katılıma Etkisi. Ankara Üniversitesi, Sosyal Bilimler Dergisi, 2, 64-104. https://doi.org/10.1501/sbeder

[15] E. B. (2019). CHP Avcılar Former District Chairman, Former Provincial Assembly Member Interview. Orhan Albayrak, Istanbul, 28 March 2020.

[16] Göksu, V. (2015). Sosyal Medyanın Kamuoyu Oluşturma ve Siyasal Katılma Üzerine Etkileri: Kuramsal ve Ampirik Bir Analiz. In Doktora Tezi. Selçuk Üniversitesi, Konya.

[17] Güngör, S. (2017). Siyasetin @Hali: Digital Çağda Siyasal Katılım e-politics: Political Participation in The Digital Age. İktisadi ve İlimler Fakültesi Dergisi, 22 (15), 2259-2273.

[18] Gürbüz, G. (2014). Sosyal Medya ve Demokrasi İlișkisi: Türkiye'de Sosyal Medyanın Katılımcı Demokrasiye Etkisi Üzerine Bir Alan Araştırması. In Yüksek Lisans Tezi. Atatürk Üniversitesi, Erzurum.

[19] Heim, M. H. (1994). The Metaphysics of Virtual Reality (First Ed.). London: Oxford University Press.

[20] H. İ. (2019). Ak Parti Avcılar Greater Municipality Council Member, Ak Parti Former District Board Member, Istanbul Provincial Council Former Chairman. Interview. Orhan Albayrak, Istanbul, 21 March 2019.

[21] M. H. (1994). The Metaphysics of Virtual Reality. (First Edit). Oxford University Press, London.

[22] Kadıbeşegil, S., \& Largo, E. (2018). Siyasi Partiler Kurumsal
Yönetim Klavuzu. In Türkiye Kurumsal Yönetim Derneği, Ankara.

[23] Kitcat, J. P. (2003). "Click here for Participation" The Role of the Internet in Party Political Participation (Issue August).

[24] Lister, M., Dovey, J., Giddings, S., Grant, I., \& Kelly, K. (2009). New Media: A Critical Introduction (Second Edi, p. 404). Routledge Taylor and Francis Group, NewYork.

[25] Manovich, L. (2001). The Language of the New Media. MIT Press, Massachusetts.

[26] Miş, N., \& Aslan, A. (2018). Ak Partinin 15 Y1lı-Siyaset (M. A. Memmi (ed.); 1. Baskı). Seta Kitapları, İstanbul.

[27] Poguntke, T. (2002). "Party Organizational Linkage: Parties Without Firm Social Roots?" Political Parties in the New Europe (K. R. Luther \& F. Müler-Rommel (eds.)). Oxford University Press, London.

[28] ROT Court of Appeals Chief Prosecutor's Office. (2020). Political Party General Information. Access Date: 7.7.2020. https://www.yargitaycb.gov.tr/kategori/109/siyasi-parti-genelbilgileri

[29] Şentürk, İ. H. (2014). Türk Hukukunda Siyasi Parti Sicillerinin Tutulması. Uyuşmazlık Mahkemesi Dergisi, 4 (4), 459-495.

[30] Skiera, B., Hennig-Thurau, T., Malthouse, E., Friege, C., Gensler, S., Lobschat, L., \& Rangaswamy, A. (2010). The Impact of New Media on Customer Relationships. Journal of Service Research, 26. https://doi.org/10.1177/1094670510375460

[31] Yayla, A. (2012). Siyaset Teorisine Giriş. In E. Saltık (Ed.), Kesit Yayınları, İstanbul (5. Baskı). Kesit yayınları. 